\title{
Difference of the size of average crown width first molar and second molar mandible of the Pawon Man with modern man
}

\author{
Taufik Senjaya*, Fahmi Oscandar*, Lutfi Yondri** \\ *Department of Dentomaxillofacial Radiology Faculty of Dentistry Universitas Padjadjaran \\ ${ }^{* *}$ Main Researcher, Division of Prehistorical Bandung Archaeological Center
}

\begin{abstract}
Introduction: Pawon Man is prehistoric human who was expected life about 9525-5660 BC and have lived in a Cave Pawon located in Mountain Masigit Village, District Cipatat, Bandung Regency. The purpose of this research to analyzed the difference size of average crown width first molar and second molar mandible Pawon Man with Modern Man. Methods: The research used a descriptive method, so that from 4 archives radiograph Pawon man, can be obtained 14 samples radiographs Cone Beam Computed Tomography first tooth molars and second molars mandible. The research conducted on Ez Implant-3D program using a digital ruler, measurement results then recorded in tabular form, then statistically analyzed using independent two-sample t test. Results: The average size of widht crown first tooth molars and second molars mandible were larger for Pawon Man teeth than Modern Man. Conclusion: The average size of widht crown first tooth molars and second molars mandible were larger for Pawon Man teeth, because Pawon Man eating hard food and rough textured with simple food processing, with transition of culture has changed the dietary and food technology, so the shape of the big teeth are no longer needed.
\end{abstract}

Keywords: Cone beam computed tomography, Pawon Man, tooth size.

\section{INTRODUCTION}

The Pawon Man is a prehistoric man who is estimated to have lived around 9525-5660 BC and had lived in the Pawon Cave. Jean Cristope (August, 2009) a French archeologist, using the C-14 calendar, Jean Cristope estimates that the Pawon Human skeleton is the oldest skeleton ever found in Western Indonesia. ${ }^{1}$

The results of excavations conducted by Yondri (2003, 2005, 2009 and 2010) in Pawon Cave, actually not only human skeletons were found, but various leftovers in the form of bone fragments of hunted animals, molluscs, the rest of good living equipment made of stone and bones, and various forms of prehistoric jewelry were also found (Figure 1). 2-5

Human teeth have come to the attention of scientists outside dentists such as scientists in the fields of anthropology, archeology, paleontology, anatomy and genetics. All works of human anthropology are accompanied by observations of tooth morphology, because teeth consist of material that is most resistant to erosion and destruction. ${ }^{6}$

This study uses radiographic techniques. The radiographic technique used is Cone Beam Computed Tomography. Cone Beam Computed 


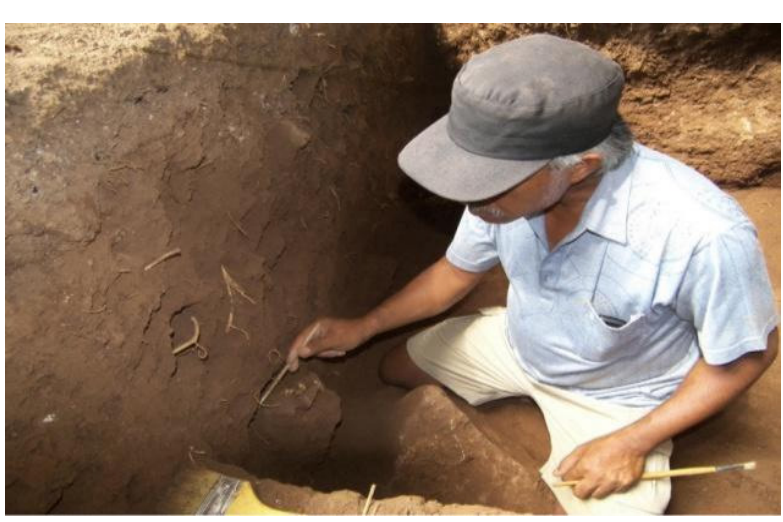

Figure 1: Opening the excavation box conducted by the Bandung Archelogy Center Team

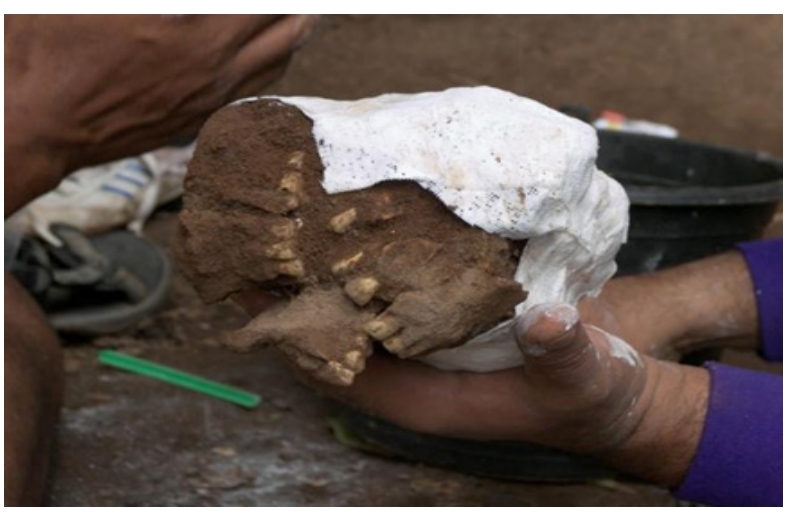

Figure 2: Discovery of Human Pawon I framework

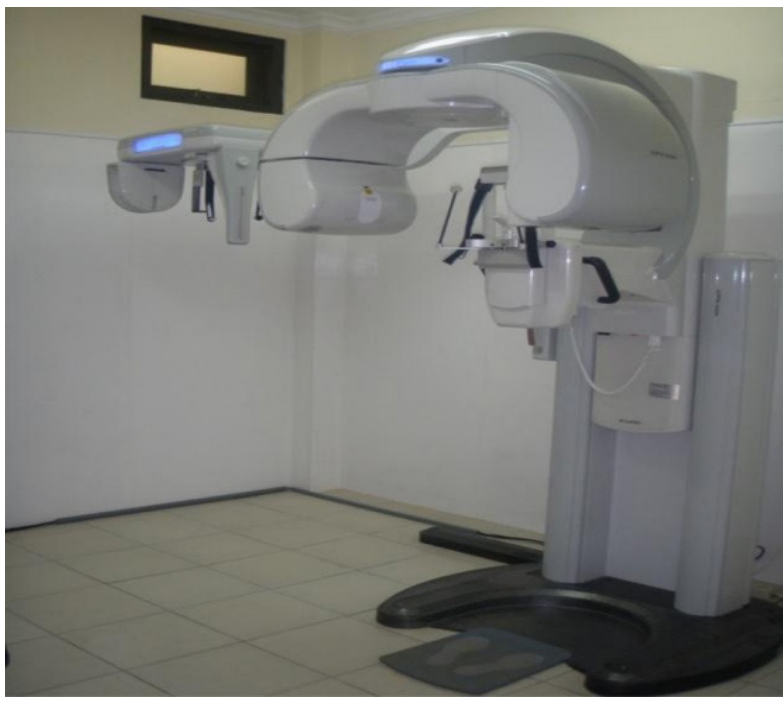

Figure 3. Cone Bean Computed Tomography

Tomography $(\mathrm{CBCT})$ is a radiographic technique that utilizes cone $\mathrm{x}$-rays and computerized volumetric reconstructions that produce threedimensional radiographs that are sagittal, coronal, axial and can provide volume sharpness and high resolution at each image projection and then be displayed specifically (image projection)(Figure 2). ${ }^{7,8}$

X-rays are presented in the form of a cone (cone) at one time exposure, allowing this tool to make many radiographs from various angles, so that the area that can be used for observation is also more, and with the help of computerized reconstruction, radiography of the subject can be reconstructed in three-dimensional shape, high resolution, and free of artifacts. ${ }^{9}$ Figure 3 . Picasso Trio Type Cone Beam Computed Tomography Tool

Cone Beam Computed Tomography will provide data in the form of volumes and images in a three-dimensional view. Image reconstruction using volumetric data cone beam. This technology produces images with a spatial resolution submillimeter, making it ideal for scandentomaxillofacial computed tomography Figure $3 .{ }^{10}$ The advantages of Cone Beam Computed Tomography compared to conventional computed tomography machines include lower exposure doses, fast radiation exposure time, smaller and lighter equipment, three-dimensional radiographs can be manipulated, facilities available to measure length, slope degree, arch length, bone density level, and so on. ${ }^{11}$ The purpose of this research to analyzed the difference size of average crown width first molar and second molar mandible Pawon Man with Modern Man.

\section{METHODS}

This type of research used in this research is descriptive research. The population in this study is the Pawon Man who is estimated to have lived around 9525-5660 BC and had lived in the Pawon Cave located in Gunung Masigit Village, Cipatat District, West Bandung Regency. Samples were obtained as many as 4 adult individual skeletons and obtained as many as 14 human mandibular molar teeth found in Pawon Cave, Gunung Masigit Village, Cipatat District, West Bandung Regency, a collection from the Bandung Archaeological Center.

The variable sought in this study is the difference in crown width size of the first molar and mandibular second molar of the Pawon Man and Modern Man. The crown width of the mandibular first molar and second molar is the width between the contact points of the mesial and distal sides of the proximal teeth of the first 


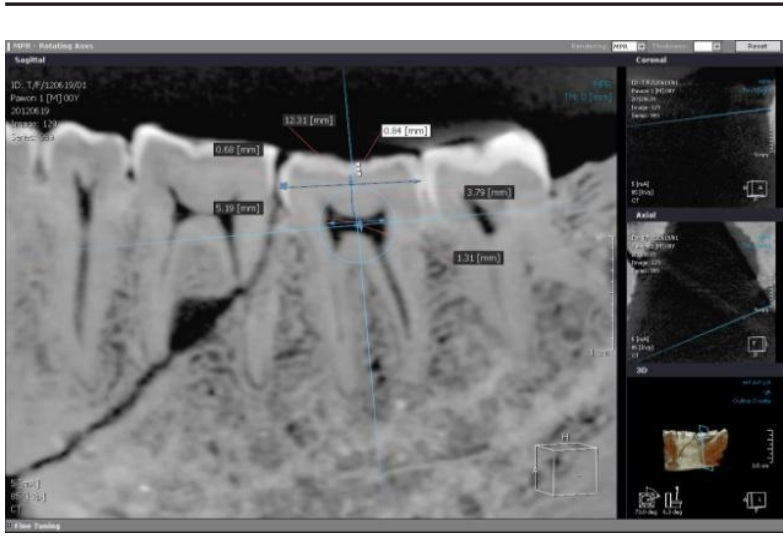

Figure 4. Measurement of the Crown Width of the Left Second Molar of the Human Mandibular Pawon I/ Frame V

molar and mandibular second molar of the human Pawon and Modern Man, measured using a digital ruler found in the Ez Implant Cone Beam Computed Tomography 3- software $D$ in millimeters $(\mathrm{mm})$ (Figure 4).

\section{RESULTS}

The results of this study are the average size of the results of measurements of the mandibular molar crown width measurements taken on each tooth using a digital ruler.

Specimens studied were Human Pawon: Pawon Cave Masigit Village, Cipatat District, Bandung Regency, Bandung Archaeological Institute collection. Modern humans: RSGM Patients in the Faculty of Dentistry, Padjadjaran University, Bandung (2011-2012).

Table 2 shows that the difference in size of the mesiodistal width of the crowns of teeth between the mandibular mandibular first molar teeth and the modern human mandibular first molar teeth. The average crown width of mandibular first molars in Human Pawons was 11.74 with a standard deviation of 0.68 . The average width of a mandibular first molar crown in Modern Humans is 11.06 with a standard deviation of 0.32 .

Based on the test criteria, it was concluded that the average mesiodistal width of the mandibular first molar crowns of the Human Pawon was significantly different from the mesiodistal width of the mandibular mandibular first molar crown at $95 \%(p=0.05)$.

Table 3 shows the difference in size of the mesiodistal width of the crowns of teeth between the mandibular second molar teeth of the Human
Tabel 1. Number of Mandibular Molar measured

\begin{tabular}{rccccc}
\hline & \multicolumn{3}{c}{ Gigi no. } & & \\
\cline { 2 - 5 } & 3.6 & 3.7 & 4.6 & 4.7 \\
\hline Human Pawon & 3 & 3 & 4 & 4 \\
Modern human & 4 & 4 & 4 & 4 \\
\hline
\end{tabular}

Tabel 2. Descriptive statistics of the average width of the crowns of mandibular first molar teeth in Human Pawons and Modern Humans

\begin{tabular}{cccccc}
\hline Variabel & Grup & $\mathrm{n}$ & $\mathrm{X}(\mathrm{mm})$ & S.D. P value & \\
\hline LM & MP & 6 & 11,74 & 0,68 & $0,062^{*}$ \\
& MM & 7 & 11,06 & 0,32 & \\
\hline
\end{tabular}

Note: * $p<0,05$; LM, crown width; MP, Human Pawon, MM, Modern Human

Tabel 3. Descriptive statistics of the average width of the crowns of mandibular teeth of the second molar man and modern humans (in $\mathrm{mm}$ )

\begin{tabular}{cccccc}
\hline Variabel & Grup & $\mathrm{n}$ & $\mathrm{X}(\mathrm{mm})$ & S.D. P value & \\
\hline LM & MP & 6 & 11,61 & 0,51 & $0,003^{*}$ \\
& MM & 7 & 10,65 & 0,49 & \\
\hline
\end{tabular}

LM, crown width; MP, Human Pawon, MM, Modern

Pawon and the mandibular second molar teeth of a Modern Human. The average crown width of the second molar teeth in the Pawon Man was 11.61 with a standard deviation of 0.51 . The average crown width of mandibular second molar teeth in Modern Men is 10.65 with a standard deviation of 0.49 . Based on the test criteria, it was concluded that the average mesiodistal width of the mandibular second molar crown of the Human Pawon was significantly different from the mesiodistal width of the mandibular second molar crown of Modern Humans at the test level of 99\% $(p=0.01)$.

\section{DISCUSSION}

The results showed that the sagittal view of the Pawon Man and Modern Man from the imaging of the Cone Beam Computed Tomography showed that the crown width of the teeth of the first molar and mandibular second molar of the human Pawon was greater than the width of the crown of the teeth of the first molar and the second molar of the mandible of the Modern Man.

Pawon Humans have large first molar teeth and mandibular second molars because 
Pawon Humans more often use their teeth to eat hard and rough-textured food with very simple food processing, finding tools from excavations conducted by the Bandung Archeology Center were found including rock material in the form of shale tools and stone tools, bone tools in the form of taper and spatula, it is evident that the Pawon Man processed prey food with a simple tool, another discovery was the discovery of mollusk fragments and vertebrate animal remains, from the many findings of possible fauna remains The most consumed by Pawon Man is from freshwater mollusks, mammals, then reptiles, and at least avesta, another thing that allows changes in the size of the mandibular molar crown widths are adaptation mechanisms to climate change (getting colder) and population growth me according to Arif et al and Mokhtar. 3,12,6

Modern humans do not use their teeth to carry out the heavy mastication process as in Human Pawons. Modern humans have a longer history of using cooked food and using tools. Modern humans eat soft food and use their tools to process food. Modern humans don't use teeth as much as food processors like Pawon Humans.

Pawon Man uses his teeth more often and teeth work harder than the Modern Human population, from the results of excavations carried out by the Bandung Archaeological Center in 2003 and 2004, no container was found to store food, so it is likely that the Pawon Man when getting food from hunted, not through the process of storing food first, but the game is directly consumed prey.

Tooth reduction in several fields has been influenced by technological shifts, especially in terms of how to process food. Once the use of tools becomes more frequent and food goes through a cooking process, so food becomes softer, humans no longer need to have large tooth sizes.

\section{CONCLUSION}

Difference in the average size of the crown width of the first molar and mandibular second molar of the Pawon Man is greater than that of the Modern Man, because the Pawon Man eats hard and coarse-textured food with simple food processing.

\section{REFERENCES}

1. Yondri, L. 2003. Laporan Kegiatan Ekskavasi Di Situs Gua Pawon, Desa Gunung

2. Masigit Kabupaten Bandung, Provinsi Jawa Barat. Balai Arkeologi Bandung

3. Yondri, L. 2005. Kubur Prasejarah Temuan Dari Gua Pawon Desa Gunung Masigit, Kabupaten Bandung Provinsi Jawa Barat: Tesis

4. Yondri, L. 2009. Laporan hasilpenelitian prasejarah penggalian arkeologi (ekskavasi) di gua gunung tanjung di sekitar kawasan gua pawon, desa gunung masigit kec. Cipatat, kabupaten bandung barat propinsi jawa barat. Balai arkeologi bandung.

5. Mokhtar, M. 1982. Masalah gigi berjejal : suatu studi perbandingan morfologi gigi, ukuran gigi dan ukuran lengkung rahang pada suku Batak dan suku Melayu di Sumatera Utara: Disertasi

6. Goaz, W. P; White, S.C.2003. Oral Radiology: Principles and Interpretation. Edisi ke-7. St. Louis, Missouri. Mosby Company, 84-92

7. Cha JY, Mah J, Sinclair P. Incidental findings in the maxillofacial area with 3-dimensional cone-beam imaging. Am J Orthod Dentofacial Orthop 2007;132: 7-14.

8. Sharon, L.B. 2005. 3D Diagnostic in Dental Office ( Major CBCT vs Dental X-ray) Disadur dari www.satellitegroup.ru (diakses Januari 2010).

9. Aya, Yajima, et all. 2006. Cone Beam CT (CBThrone) Applied to Dentomaxillofacial Region. The Bulletin of Tokyo Dental College Vol.47. Diambil dari www.tmjournal.com (diakses Januari 2010).

10. Araki, dkk. 2004. Characteristict of a newly developed dentomaxillofacial X-ray cone beam CT scanner. Disadur dariwww. BritishInstituteofRadiolo gy.com (diakses Desember 2011).

11. Arif, J., Mark R.Schurr, Rubyanto Kapid. 2008. Evolutionary molar size reduction in Javanese early Pleistocene Homo erectus and Indonesian Mesolithic-Neolithic Homo sapiens: effect of paleo-climatic change. Unpublished. 